\title{
ARE ISLAMIC STOCKS LESS EXPOSED TO SENTIMENT- BASED MISPRICING THAN NON-ISLAMIC ONES? EVIDENCE FROM THE INDONESIAN STOCK EXCHANGE
}

\author{
Rizqi Umar Al Hashfi ${ }^{1}$, Ahmad Maulin Naufa ${ }^{2}$ and U'um Munawaroh ${ }^{3}$ \\ ${ }^{1}$ Faculty of Islamic Economics and Business, State Islamic University of Sunan Kalijaga, Indonesia, \\ alhashfi1992@gmail.com \\ ${ }^{2}$ BINUS Business School, Bina Nusantara University, Indonesia, ahmad.maulin@binus.ac.id \\ ${ }^{3}$ Faculty of Economics and Business, Universitas Gadjah Mada, Indonesia, \\ uummunawaroh@mail.ugm.ac.id
}

\begin{abstract}
The aim of this research is to verify the role of Islamic value in stock mispricing in the Indonesian capital market. Empirically, high investor sentiment can lead to mispricing on equity appraisal. When investors feel excessively optimistic about their valuation, equity will be overpriced, or vice versa. The presence of Islamic values, such as the prohibition of interest, speculative and uncertain transactions, and excessive leverage, arguably reduce sentiment-based mispricing. Daily and cross-sectional market data were employed. In addition, principal component analysis was conducted to construct a firm-specific investor sentiment variable. With regard to the method, the Hausman-Taylor (H-T) approach was used to deal with heterogeneity, endogeneity, and the time-invariant variable in Fama-MacBeth regression. The results show that our baseline analysis confirms the mispricing of overall stocks. However, Islamic stocks are less exposed to sentiment-based mispricing than their non-Islamic counterparts. The results are consistent with our robustness test, in which we estimate the equation model across industry and portfolio. Finally, our findings imply various insights for both investors and policymakers.
\end{abstract}

Keywords: Mispricing, Sentiment, Return, Islamic values.

JEL classification: C23; G10; G41.

Article history:

Received : October 15, 2020

Revised : : February 11, 2021

Accepted : February 2, 2021

Available online : February 28, 2021

https://doi.org/10.21098/jimf.v7i1.1319 


\section{INTRODUCTION}

\subsection{Background}

Recently, the financial market has been in a volatile, uncertain, complex and ambiguous (VUCA) world, one in which economic agents tend to be irrational and most of their decisions become speculative. The history of crises, such as the dotcom bubble of 2001 and that related to subprime mortgages in 2008, has shown that economic turmoil resulting from financial market crashes leads to irrational pricing. This then creates asset bubbles, in which performance is not compensated by the high value pinned. When the bubbles burst, prices return to reality. This is why increased asset prices will be followed by dramatically sharp declines.

The presence of noise pricing in the financial market challenges traditional finance tenets such as the capital asset pricing model, the efficient market hypothesis (EMH), and arbitrage pricing theory (Fama, 1991; Lintner, 1965; Ross, 1976; Sharpe, 1964). In the traditional approach, rational frameworks situate investors as risk-averse beings and drive asset prices to fundamental values. For instance, according to $\mathrm{EMH}$, asset prices in the financial market randomly walk, so it is not easy to predict their future value with new information. In fact, market participants tend to give excess weight to new information, ignore prospects, and feel over-confident in their capabilities (Statman, 2014). These actions are the root of market crashes and cannot be explained by conventional finance. Therefore, behavioral finance is needed to explore in-depth mispricing in the capital market.

In behavioural finance, investors are assumed to have bounded rationality and be driven by psychological factors in their decision-making processes. Furthermore, they may feel optimistic or pessimistic about market prospects and unanticipated future cash flows. Some studies define feelings as investor sentiment (Aggarwal, 2019; Baker \& Wurgler, 2007; Dai \& Yang, 2018; Zhu et al., 2020). When investors are excessively optimistic (or pessimist) about a stock or portfolio, they can create demand (or supply) shock, which can then cause stock prices to deviate from their fundamental value (Mendel \& Shleifer, 2012; Stambaugh \& Yuan, 2017). Therefore, unpredictable changes in sentiment could have recently affected stock prices (Ahmed, 2020; Allen et al., 2019; Cagli et al., 2020; Liston-Perez et al., 2018).

Even if investor sentiment is a notable factor in equity valuation, its intensity varies depending on country and stock characteristics (Baker et al., 2012; Corredor et al., 2013). In emerging economies, sentiment-based mispricing is relatively more intense due to the frequent occurrence of herding behaviour and overreaction (Zhang et al., 2019), together with a lack of institutional involvement, investor protection, and qualified information (Anusakumar et al., 2017; Chen et al., 2013; Pandey \& Sehgal, 2019). Moreover, some studies confirm that the extent to which sentiment effects returns can be distinguished by its extent (Huang et al., 2015; Qadan \& Aharon, 2019) and ethical value (Aloui et al., 2016; Keleş \& Çetin, 2018) embedded within a stock or portfolio. Small stocks are arguably more exposed to sentiment than large ones, whereas ethical-based stocks have low sensitivity to sentiment.

As a part of the ethical fund market (Hussein \& Omran, 2005), the Islamic stock market has been growing considerably in the aftermath of the global financial crisis of 2008 (Ibrahim, 2015; Masih et al., 2018). According to IFSB (2020), Islamic equity had double-digit growth performance (29.8\%) and outperformed its global 
counterparts in 2019. Empirically, some studies have verified the distinction between Islamic and conventional stocks in terms of their risk and return profile (Ahmed, 2018; Al-Khazali et al., 2014; Alam \& Ansari, 2020; Dharani et al., 2019; Reddy et al., 2017; Walkshäusl \& Lobe, 2012). It is inseparable from the screening mechanism in establishing the Islamic stock index. Besides having to comply with sharia values, Islamic stocks must have a low debt ratio and non-halal income.

However, whether Islamic stocks are immune to sentiment-based mispricing is still a matter of academic debate. On one hand, both Islamic or conventional stocks are exposed to sentiment (Aloui et al., 2016; Liston-Perez et al., 2018; Perez-Liston et al., 2016). On the other hand, Islamic stocks are hedged against sentiment (Dash \& Maitra, 2018). Therefore, our ultimate objective is to analyse the relationship between Islamic values and sentiment-based mispricing in stock valuation. In more detail, we chose the Indonesian stock market as our sample since the country, an emerging economy, has a potential Islamic stock market whose market capitalisation share had reached $51.55 \%$ by the end of 2019 (OJK, 2018). In terms of risk, return, and co-movement, Indonesian Islamic stocks are considered to benefit from diversification (Lusyana \& Sherif, 2017; Majdoub et al., 2016; Qoyum et al., 2020).

Some issues arise regarding methods to empirically study sentiment-based mispricing. The first is that several research fields concern market-wide sentiment, while others suggest investigating at the firm level (Fu et al., 2020; Lan et al., 2020). Because of firm characteristics, the mispricing process can be explained serially and cross-sectionally. Second, due to the high sensitivity to new information or specific events, investor sentiment may change dynamically on a daily basis. It is considered to use high-frequency rather than low-frequency data (Seok et al., 2019a, 2019b).

Our research contributes to the field in various ways. First, to the best of our knowledge, studies examining the role of Islamic value in the sentiment-return relationship are limited, and their results are inconclusive. Therefore, we aim to fill this research gap. Second, we conducted principal component analysis, as previous studies have suggested constructing a firm-specific sentiment index (Ryu et al., 2017; Seok et al., 2019a). This method is conducted at firm-level and embraces all sentiment indicators, therefore leading to precise measurements. Third, we conducted split-sample regression based on industry characteristics and size portfolios to confirm our results.

To establish our sample, we selected all firms that had been consistently registered on the Indonesia Stock Exchange from 2012 to 2018 and had not booked negative stockholder equity. In addition, we employed the Hausman-Taylor estimator for the error component model to overcome endogeneity, heterogeneity, and the presence of a time-invariant variable in estimating Fama-MacBeth regression. Our baseline analysis indicates that firm-specific investor sentiment is positively linked to overall stock returns. However, the effect of sentiment on stock return weakens on Islamic stocks. Third, these results remain the same as in the robustness check (industry and size portfolio regression). Therefore, Islamic stocks are less mispriced than their conventional counterparts. These findings imply that investors and policymakers should develop an Islamic stock market in Indonesia. 


\subsection{Objective}

Our study first aims to examine whether firm-specific sentiment is associated with stock return. The second objective is to clarify whether Islamic shocks are less exposed to sentiment-based mispricing. The paper is organised to realise our goals as follows. The following sections present the literature review, research methods, results, discussion, robustness checks, and conclusion.

\section{LITERATURE REVIEW}

\subsection{Theoretical Background}

In traditional finance, investors are assumed to be rational beings. By firmly clinging on it, the capital asset pricing model (CAPM) and multifactor models were developed to explain stock price movement (Amihud, 2002; Carhart, 1997; Fama \& French, 1992; Jensen, 1968; Lintner, 1965; Sharpe, 1964). In addition, markets are hypothetically efficient, in that asset prices fully reflect available market information (Ackert \& Deaves, 2010). It is hard to chase abnormal returns under the circumstance since stock prices are walk randomly and quickly adjust to new information. Stock prices are therfore always equal to their intrinsic value (Barberis \& Thaler, 2002).

In fact, market players are faced with speculative behaviours. First, the lesson from the global financial crisis of 2007-2008 shows that overconfidence in appraisal creates an asset price bubble (Filbeck et al., 2017). When market agents realise their error, the bubble bursts, and the stock market crashes. Second, the presence of noise traders, who rely on technical analysis rather than on the fundamental side to profit , potentially leads to systematic noise price (Barber et al., 2009; Ramiah et al., 2015). On several occasions, they have over- or under-reacted to new information, and in some cases have utilised uncertain events to increase demand shock and subsequently distort stock prices. Hence, two shreds of the evidence challenge the rationality assumption and efficient market hypothesis (EMH).

Behavioural finance, a combination of financial theory, psychology and sociology, emerged to explain what was lacking in traditional views (Statman, 2014). The body of knowledge assumes that some market players are not fully rational in their asset valuation. For instance, if there are two stocks that have an identical present value of cash flow, but one stock is valued higher than the other, the EMH suggests that the stock prices will converge through an arbitrage process by which rational market agents buy (sell) stocks at low (high) prices simultaneously. However, there might be a limit to arbitrage even if market participants are entirely rational, thus leading to advanced mispricing (Barberis \& Thaler, 2002; Glaser et al., 2004).

In their experimental work, Bloomfield et al. (2009) further explain the pros and cons of noise traders. On one hand, they generally reduce bid-ask spreads so that market liquidity increases. On the other, they have the potential to further distort prices, thereby disrupting price adjustments even when the market is efficient. This relates to investor sentiment toward a stock or portfolio.

Sentiment is expressed as investors' attitudes towards the financial market (Shleifer \& Summers, 1990). It is a form of belief that results in over- or underreaction to stocks (Berberis et al., 1996), with speculation on cash flow based on noise (Baker \& Wurgler, 2007); optimism or pessimism towards financial market 
(Baker \& Wurgler, 2006); relative market expectations towards the norm (Brown \& Cliff, 2004); or close investor belief in fundamental value (Mendel \& Shleifer, 2012). In addition, sentiment is related to noise traders who make irrational investment decisions and do not trade on basis information (Black, 1986).

Brown and Cliff (2004) argue that sentiment occurs over the long term, as noise traders are excessively confident in their appraisal, resulting in the existence of high demand shocks. Subsequently, stock prices deviate from their fundamental value. The long-term effect of sentiment may create a barrier to conducting arbitrage. Moreover, most investors in Asian economies are more likely to experience more cognitive bias than those in the west (Kim \& Nofsinger, 2008), as they adhere to a collective social paradigm in which individuals tend to be overconfident.

\subsection{Islamic Equity Screening and Development}

Islamic and ethical finance have a similar objective, in that individuals allocate their funds in a manner consistent with their morals and faith (Bennett \& Iqbal, 2013). More specifically, morals in Islamic finance emphasise investing activity that complies with sharia principles (Lusyana \& Sherif, 2017). There are many investment instruments in the Islamic capital market, including Islamic stocks, sukuk, and Islamic mutual funds. Those originate from conventional ones screened by the sharia board based on qualitative and quantitative criteria (Adam \& Bakar, 2014).

The first screening is conducted to eliminate prohibited business activities, which are gambling (maysir), extreme uncertainty (gharar), interest-bearing transactions (riba), and all others wbhich are strictly banned (haram) in Islam. The second relates to business that is permitted (halal) under sharia principles and meets financial screening provision (Ashraf, 2016; Jaballah et al., 2018). At this level, financial-ratio requirements vary over institutions and countries, but overall the ratio of debt, non-halal income, and receivables are mostly predetermined criteria.

As a capital market supervisor in Indonesia, BAPEPAM-LK released the List of Sharia Securities (DES) in 2009 and then founded the Indonesian Islamic

Table 1.

ISSI Sharia-Based Screening Criteria

\begin{tabular}{ll}
\hline Qualitative Screening & \multicolumn{1}{c}{ Quantitative Screening } \\
\hline Prohibited business activity: & Financial screening: \\
$\begin{array}{ll}\text { (1) Gambling. } & \text { (1) Total interest-based debt/total assets }<45 \% . \\
\text { (2) Trade indicated to have created counterfeit supply/ } & \text { (2) Total interest and non-compliant activities } \\
\text { demand for goods or services. } & \text { income/revenue and other income }<10 \% . \\
\text { (3) Financial service providers such as interest-based } & \\
\text { banks or interest-bearing financing. } & \\
\text { (4) Excessive uncertainty (gharar) in buying and selling } & \\
\text { transactions. } & \\
\text { (5) Producing, distributing, and trading goods/services } & \\
\text { banned by sharia (haram). } & \\
\text { (6) Bribery transactions. }\end{array}$ \\
\hline
\end{tabular}

Source: OJK (2017) 
stock index (ISSI) in 2011 as an Islamic stock market benchmark. The institution constructs the Islamic screening process according to certain criteria (Table 1).

Globally, the Islamic stock market has experienced tremendous growth in the aftermath of the global financial crisis of 2008 (Ibrahim, 2015; Masih et al., 2018). IFSB (2020) records that the Islamic equity market achieved it highest year-on-year growth $(29.8 \%)$ and outperformed its non-Islamic counterparts in 2019. Incorporating sharia principles in investment decisions is considered to be a differentiating factor, at the same time promoting Islamic stock performance (Ahmed, 2018; Al-Khazali et al., 2014; Reddy et al., 2017; Walkshäusl \& Lobe, 2012).

Moreover, to improve performance, embracing Islamic values in investing is viewed as a way to reduce sentiment-based mispricing. On the principle of prohibiting speculation (maysir), investors must verify all the information received and should not have unrealistic expectations, or be too optimistic or pessimistic (Erdogan et al., 2020). In addition, as part of ethical finance, the price of Islamic funds tend to be stable, since being part of ethical-based investment, they receive more coverage from analysts than their non-Islamic counterparts (Hong \& Kacperczyk, 2009). Finally, limits on the ratio of interest-based debt and income lower credit risk and thus reduce price volatility (Zaremba et al., 2018).

Islamic equity dominates, with a $51.55 \%$ share of total market capitalisation in Indonesia (OJK, 2018). Some studies have investigated the diversification benefit of the Indonesian Islamic stock market. Majdoub et al. (2016) suggest that Indonesian Islamic stocks offer international diversification due to their low comovement with the stock market in developed countries. Moreover, in terms of the risk-return profile, Islamic portfolios have low systematic risk and outperform their non-Islamic counterparts (Lusyana \& Sherif, 2017; Qoyum et al., 2020).

\subsection{Previous Studies}

We document the most recent studies investigating the sentiment-return relationship. Ryu et al. (2017) investigated the link between investor sentiment, trading behaviour, and equity returns in the Korean market. Investor sentiment was proxied by a composite measure consisting of the relative strength index (RSI), psychological line index (PLI), adjusted turnover rate (ATR), and the natural log of trading volume (LNV). The sentiment index was then created using principal component analysis. Ryu et al. concluded that investor sentiment was more powerful in predicting stock returns than trading behaviour. In more detail, they classified investors into individual and institutional ones; empirically, the sentiment effect on individual investors was higher than on institutional ones.

Liston-Perez et al. (2018) used DCC-GARCH to capture the time-varying relation between investor sentiment and stock returns. Their results confirm that the association varies over time, but that overall investor sentiment negatively effects one-step-ahead equity return. Hence, high sentiment leads to a decrease in the stock price in the following period. Moreover, this finding clarifies the efficient market hypothesis, in which arbitrageurs will force mispriced stocks back to their fundamental value.

Rahman and Shamsuddin (2019) analysed investor sentiment and the priceearnings ratio (PER). Employing samples from G7 stock markets, they found 
that a high price-earnings ratio followed high sentiment. This phenomenon was explained by Baker and Stein (2004) and Baker and Wurgler (2007). In predicting future value from cash flow and risk, market participants tend to give excessive weight to new information, neglect prospective issues, and are overconfident in their ability. Therefore, the PER ratio increases over time in line with the rise in investor sentiment.

Seok et al. (2019a) explored the effect of firm-specific investor sentiment on stock returns. Unlike Ryu et al. (2017), they developed the sentiment index using the residuals of RSI, PLI, ATR, and LNV, which was intended to replace marketwide sentiment to obtain firm-level sentiment. Seok et al.'s research also suggests employing high-frequency data (daily and Fama-French-Carhart factors), in explaining other factors beyond investor sentiment. Furthermore, they adopted Fama \& MacBeth's (1973) regression on the equation model. Their findings show that firm-specific investor sentiment positively effects daily stock returns.

Bannigidadmath (2020) examined the link between consumer sentiment and stock returns on the Indonesia Stock Exchange. The empirical work suggests that stock returns are well predicted by consumer sentiment. However, the research was only on three out of nine industries and not on the aggregate market. Moreover, the oil and gas sectors are more exposed to consumer sentiment, as they are the most volatile industries associated with local and global shock.

Not only can sentiment explain mispricing of equity, but it can also predict stock market crashes or crises. Zhang et al. (2019) and Fu et al. (2020) confirmed the contribution of firm-specific investor sentiment to predicting stock market crashes. These studies were motivated by the inability of traditional financial theory to explain anomalies such as excessive volatility and mispricing of stock and mutual funds. When noise traders feel over-optimist about a stock appraisal, they may push its price to a high level. Furthermore, during a period of high sentiment, analysts tend to predict optimist earnings, so negative information cannot be captured at the right time on the external investor. Therefore, managers might not disclose bad news during periods of high sentiment. When information is accumulated to its highest point, it will be released once, causing a stock market crash. Cui and Zhang (2019) also confirm that the impact of investor sentiment on the risk of stock price crashes is more obvious in firms with a greater leverage ratio, higher default risk, and wider analyst forecast dispersion.

While many studies affirm the effect of sentiment on stock valuation, others examine whether ethical investing shapes sentiment-based mispricing. Moral investing covers the socially responsible (environmental, social, and governance/ ESG) and religious-based assets or portfolios (Azmi et al., 2019). Keleş and Çetin (2018) found that the sentiment-return relationship in high ESG-score firms was less significant than that in low ESG-score ones.

Hong and Kacperczyk (2009) demonstrated that ethical equities were mostly owned by institutional investors rather than individual ones. Conceptually, institutional investors, such as insurance companies, banks, regional institutions and universities are well-informed, sophisticated and rational arbitrageurs, whereas individual investors are known to be noisy traders (Koesrindartoto et al., 2020; Kumari, 2019; Ryu et al., 2017). Therefore, ethical stocks are less mispriced than their non-ethical counterparts. 
Perez-Liston et al. (2016) verified the positive effect of investor sentiment on volatility and return on the U.S. Dow Jones Islamic equity index. They utilised autoregressive conditional heteroscedasticity $(\mathrm{ARCH})$ and vector autoregressive (VAR). Based on their results, they suggest that behavioural finance theory, such as investors' mood, optimism, and pessimism, need to be incorporated into the asset pricing model alongside rational finance.

Using U.S. market data, Aloui et al. (2016) explored the sentiment-return relation in Islamic and conventional stocks. More specifically, they adopted squared wavelet coherence methodology to examine the time-varying association. In summary, there was no difference between Islamic and traditional stocks regarding the effect of sentiment on stock return. In other words, Islamic values do not play a role in shaping sentiment-return relations.

Dash and Maitra (2018) investigated the interaction between Islamic stocks, investor sentiment, and macroeconomic factors, usinf Indian stock market data and wavelet analysis. Macroeconomic factors were shown to significantly effect Islamic stock return, whereas investor sentiment did not. In this case, shariacompliant equity was immune to the sentiment-risk element. Their findings indicate that business activity and financial screening based on Sharia principles, such as the prohibition of non-ethical, interest-based and speculative transactions and the limitation on high leverage, can minimise sentiment risk.

Based on empirical study and theory, either wide-market or firm-specific investor sentiment has a systematic impact on stock returns. When investor sentiment is high, stock prices will increase dramatically and even become overvalued. This explains the fact that high investor sentiment leads to potential stock mispricing, as their values are far from being realistic. Sentiment is better for predicting stock market crises than a macro variable in a one-year time horizon. At this point, it can be said that overvaluation due to excessive optimism may be followed by a sharp decrease in prices, and may be the potential root of stock market crashes. In addition, the presence of ethical investing, such as in Islamic stocks, potentially mitigates sentiment-based mispricing on stock valuation. Therefore, the following hypothesis is proposed:

Islamic stocks are less exposed to sentiment-based mispricing than their non-Islamic counterparts.

\section{METHODOLOGY}

\subsection{Data}

We used all firms consistently registered on the Indonesia Stock Exchange from 2012 to 2018. Moreover, we omitted samples that had negative stockholder equity and were classified as non-actively-traded and suspended stocks (Qoyum et al., 2020). Therefore, the sample comprised 203 firms, of which 105 were Islamic stocks and 98 non-Islamic ones. Table 2 shows the number of stocks based on industry clusters. All the financial data, either at firm or macro level, were daily and taken from Thomson Reuters and CEIC. 
Table 2.

Number of Stocks based on Industry Classification

\begin{tabular}{lccc}
\hline Industry & NIS & IS & Total \\
\hline Agriculture & 5 & 4 & 9 \\
Basic Industries and Chemicals & 14 & 20 & 34 \\
Consumer Goods & 7 & 14 & 21 \\
Finance & 19 & - & 19 \\
Infrastructure, Utilities, and Transportation & 13 & 3 & 16 \\
Mining & 9 & 10 & 19 \\
Miscellaneous & 4 & 10 & 14 \\
Property, Real Estate, and Building Construction & 6 & 22 & 28 \\
Trade, Services, and Investment & 21 & 22 & 43 \\
\hline Total & 98 & 105 & 203 \\
\hline
\end{tabular}

We identified daily investor sentiment measures consisting of RSI, PLI, ATR, and LNV (Ryu et al., 2017; Yang \& Zhou, 2015). In Table 3, all the sentiment indicators are defined in detail. We expect that these measures will have a similar direction to each other, so that an increase in all proxies indicates higher investor sentiment.

Table 3.

Definition of Each Variable

\section{Definition and calculation}

Daily stock return

(RET)

Relative strength index (RSI) overbought or oversold (Bodie et al., 2014; Chong \& Ng, 2008) and utilised as a sentiment investor proxy (Ryu et al., 2017). The RSI equation can be expressed as follows:

$\mathrm{RSI}_{\mathrm{it}}=\left[\frac{\mathrm{RS}_{\mathrm{it}}}{1+\mathrm{RS}_{\mathrm{it}}}\right] \times 100 ; \mathrm{RS}_{\mathrm{it}}=\frac{\sum_{\mathrm{k}=0}^{13} \max \left(0, \mathrm{P}_{\mathrm{it}-\mathrm{k}}-\mathrm{P}_{\mathrm{it}-1-\mathrm{k}}\right)}{\sum_{\mathrm{k}=0}^{13} \max \left(0, \mathrm{P}_{\mathrm{it}-1-\mathrm{k}}-\mathrm{P}_{\mathrm{it}-\mathrm{k}}\right)}$

If the RSI value is 80 or above, this means that during the 13-day horizon, a stock is overbought. However, it is an oversold stock if the RSI is 20 or below.

Psychological line index (PLI) PLI is a momentum and market condition indicator (Seok et al., 2019a). It also represents the short-term price reversal psychological stability of investors. We adopted Ryu et al.'s (2017) equation as follows:

$\mathrm{PLI}_{\mathrm{it}}=100 \sum_{\mathrm{k}}^{11}\left\{\frac{\max \left(0, \mathrm{P}_{\mathrm{it}-\mathrm{k}}-\mathrm{P}_{\mathrm{it}-1-\mathrm{k}}\right)}{\mathrm{P}_{\mathrm{it}-\mathrm{k}}-\mathrm{P}_{\mathrm{it}-1-\mathrm{k}}}\right\} / 12$

A value of 75 on the PLI shows an upward trend in stock prices, whereas one of 25 indicates a downward trend in prices. 
Table 3.

Definition of Each Variable (Continued)

\begin{tabular}{|c|c|}
\hline & Definition and calculation \\
\hline Adjusted turnover rate (ATR) & $\begin{array}{l}\text { ATR can be used to measure stock liquidity (Yao \& Li, 2020), investor } \\
\text { sentiment (Baker \& Stein, 2004) and is written by the following equation: } \\
\text { ATR }_{i t}=\left[\frac{V_{i t}}{\text { OUTSHARE }} E_{i t}\right]\left[\frac{R_{i t}}{\left|R_{i t}\right|}\right] \\
\text { where } V_{i t} \text { is the trading volume of stock } i \text { on day } t \text {; OUTSHARE } E_{i t} \text { is the } \\
\text { number of outstanding of stock } i \text { on day } t \text {; and } R_{i t} \text { is daily stock return. }\end{array}$ \\
\hline $\begin{array}{l}\text { Natural log of trading } \\
\text { volume (LNV) }\end{array}$ & $\begin{array}{l}\text { LNV reflects investors' opinions regarding the equity market (Baker \& } \\
\text { Wurgler, 2007) to gauge sentiment (Liao et al., 2011; Seok et al., 2019b). We } \\
\text { calculated the natural log of trading volume as follows: } \\
\mathrm{LNV}_{\mathrm{it}}=\ln \left(\mathrm{V}_{\mathrm{it}}\right)\end{array}$ \\
\hline $\begin{array}{l}\text { Excess return of market } \\
\text { portfolio (MKT) }\end{array}$ & $\begin{array}{l}\text { Referring to Fama and French (2012) and Qoyum et al. (2020), MKT is } \\
\text { a market portfolio return over a risk-free rate (daily policy rate of Bank } \\
\text { Indonesia) based on the capitalisation-weighted average each year. }\end{array}$ \\
\hline Term spread (T.S.) & $\begin{array}{l}\text { The difference between long-term ( } 30 \text {-year) and short-term (1-year) } \\
\text { Indonesian government bond yield. }\end{array}$ \\
\hline Default spread (D.S.) & $\begin{array}{l}\text { The difference between BBB-rated corporate bond and AAA-rated } \\
\text { corporate bond yields. }\end{array}$ \\
\hline $\begin{array}{l}\text { Market capitalisation } \\
\text { (MCAP) }\end{array}$ & Multiplication of the equity price and the number of shares outstanding. \\
\hline Book-to-market (B.M.) & Shareholder equity to market capitalisation ratio. \\
\hline Price-to-earning (PER) & Stock price to earnings per share. \\
\hline
\end{tabular}

Table 3 shows a detailed description of each variable. In line with our aims, daily stock return is an explained variable. We then constructed a sentiment index as an explanatory factor. Some previous studies have suggested IPO volume, IPO first-day returns, equity share in new issues, stock turnover, closed-end fund discount, the dividend premium, and the consumer confidence index as sentiment indicators (Baker et al., 2012; Baker \& Stein, 2004; Baker \& Wurgler, 2007). Nevertheless, in an emerging market, some of these indicators are not readily available daily, if at all, so just capture overall market sentiment but take little account of firm characteristics. Therefore, we constructed the index: the combination of sentiment gauges consisting of RSI, PLI, ATR, and LNV and generated by principal component analysis (Ryu et al., 2017; Yang \& Zhou, 2015).

However, the presence of endogenous factors might be a significant issue in constructing the index. For example, market portfolio return, term spread, and default spread capture investors' outlook on overall market conditions, namely inflation, the stance of monetary policy, and fiscal deficit (Bodie et al., 2014; Gupta et al., 2019). Therefore, each sentiment indicator's standard change is predominantly prompted by endogenous factors, not firm-specific ones, especially Islamic values.

As prompted by Seok et al. (2019b) and Ryu et al. (2017), we created orthogonalised sentiment indicators exempt from overall market conditions. Furthermore, the variation in the sentiment component was only driven by the idiosyncratic features of firms. We first estimated the residual value of the following equation (Seok et al., 2019a): 


$$
\mathrm{CP}_{\mathrm{it}}=\eta_{0}+\eta_{1} \mathrm{MKT}_{\mathrm{it}}+\eta_{2} \mathrm{TS}_{\mathrm{it}}+\eta_{3} \mathrm{DS}_{\mathrm{it}}+\eta_{4} \mathrm{MCAP}_{\mathrm{it}}+\eta_{5} \mathrm{BM}_{\mathrm{it}}+\eta_{6} \mathrm{PER}_{\mathrm{it}}+\varepsilon_{\mathrm{it}}
$$

In equation (1), $\mathrm{CP}_{\text {it }}$ represents sentiment components (RSI, PLI, ATR, and LNV), and the right-hand side factors are clearly defined in Table 2 . The residuals $\left(\varepsilon_{\mathrm{it}}\right)$ represent firm-specific components, and then those are immune from overall sentiment.

We then conducted principal component analysis (PCA) using the residuals of the sentiment components and assigned $\varepsilon_{i t}^{\mathrm{RSI}}, \varepsilon_{\mathrm{it}}^{\mathrm{PLI}}, \varepsilon_{\mathrm{it}}^{\mathrm{ATR}}$, and $\varepsilon_{i \mathrm{t}}^{\mathrm{LNV}}$ to denote idiosyncratic sentiment (see equation 2).

$$
\mathrm{SENT}_{i \mathrm{t}}=0.652 \varepsilon_{\mathrm{it}}^{\mathrm{RSI}}+0.683 \varepsilon_{\mathrm{it}}^{\mathrm{PLI}}+0.160 \varepsilon_{\mathrm{it}}^{\mathrm{ATR}}+0.283 \varepsilon_{\mathrm{it}}^{\mathrm{LNV}}
$$

where $S_{i t}$ is the firm-specific sentiment index, which is expected to be $S_{i t}$ positively associated with the sentiment indicators. In Table 4 , the correlation matrix confirms the positive relationship between the indicators, which are also positively related to the firm-specific sentiment index. Finally, our PCA results are fairly similar to those of Seok et al. (2019a), with RSI and PLI having the highest correlation with SENT (above 0.80).

Table 4.

Correlation Matrix Between The Composite Sentiment Index and Investor Sentiment Indicators

\begin{tabular}{lccccc}
\hline & SENT & RSI & PLI & ATR & LNV \\
\hline SENT & 1.000 & & & & \\
RSI & 0.894 & 1.000 & & & \\
PLI & 0.846 & 0.509 & 1.000 & & \\
ATR & 0.148 & 0.084 & 0.063 & 1.000 & \\
LNV & 0.165 & 0.078 & 0.295 & 0.038 & 1.000 \\
\hline
\end{tabular}

This table shows the matrix correlation between the sentiment index and sentiment component. SENT is the sentiment index constructed from four investor sentiment indicators: the relative strength index (RSI); psychological line index (PLI); adjusted turnover rate (ATR); and the natural log of trading volume (LNV).

\subsection{Model Development}

The presence of mispricing in stock valuation can be detected from the relationship between investor sentiment and stock prices (Mendel \& Shleifer, 2012; Stambaugh \& Yuan, 2017). Some recent studies have investigated the monthly sentimentreturn relation (Ahmed, 2020; Cagli et al., 2020; French \& Li, 2017; Huang et al., 2015; Liston-Perez et al., 2018; Miwa, 2016; Yao \& Li, 2020), while others use higher time-frequency data (weekly or daily) to examine the relationship (Dai \& Yang, 2018; Fu et al., 2020; Khan et al., 2019; Ryu et al., 2017; Seok et al., 2019a). Overall, these empirical studies have found that sentiment can predict stock price movement in either contemporaneous or one-step ahead fashion.

To the best of our literature documentation (Aloui et al., 2016; Dash \& Maitra, 2018; Jaziri \& Abdelhedi, 2018), there is still academic debate over whether Islamic values moderate the sentiment-returns relationship, especially in an emerging 
market. Therefore, we contribute to the related literature gap. Our study also uses daily data for several reasons. First, changes in investor sentiment may be caused by new daily information regarding a company's prospects and market conditions, thus affecting its stock price (Allen et al., 2019; Lan et al., 2020). Second, it is essential for decisions and policies that the use of high-frequency data leads to a precise indicator for bubble pricing due to high sentiment (Fu et al., 2020).

To develop a regression model, we adopted Fama \& MacBeth's (1973) approach. Initially, the model was intended to examine the power of market beta, size, and value factors in explaining pooled cross-sectional stock return (Fama \& French, 1992; Shaikh et al., 2019). Other studies utilised these elements as control variables (Galema et al., 2008; Hong \& Kacperczyk, 2009). As we used daily data, we apply the Fama-MacBeth regression modified by Seok et al. (2019a). The authentic model consists of market beta, expected return, the log form of market capitalisation, and the book-to-market and price-to-earnings ratios. Seok et al.'s (2019a) model is composed of Fama-French-Carhart factors (Carhart, 1997; Fama \& French, 2012). Table 5 shows the configuration of the Fama-French-Carhart model (henceforth referred to as $4 \mathrm{FFC}$ ).

Table 5.

Fama-French-Carhart Model Building

\begin{tabular}{lc}
\hline Factor & Definition and calculation \\
\hline Market (MKT) & Value-weighted market portfolio \\
Small Minus Big (SMB) & $\mathrm{SMB}=(\mathrm{SH}+\mathrm{SN}+\mathrm{SL}) / 3-(\mathrm{BH}+\mathrm{BN}+\mathrm{BL}) / 3$ \\
High Minus Low (HML) & $\mathrm{HML}=[(\mathrm{SH}-\mathrm{SL})+(\mathrm{BH}-\mathrm{BL})] / 2$ \\
Upper Minus Down (UMD) & $\mathrm{UMD}=[(\mathrm{SU}-\mathrm{SD})+(\mathrm{BU}-\mathrm{BD})] / 2$ \\
\hline
\end{tabular}

This table shows the definition and calculation of the 4FFC equation. Portfolios constitute 4FFC, namely, smallhigh (S.H.), small-neutral (S.N.), small-growth (S.H.), big-high (B.H.), big-neutral (B.N.), big-low (B.L.), small-down (S.D.), small-upper (S.D.), big-down (B.D.), and big-upper (B.U.). We then arranged SMB, HML, and UMD built upon capitalisation, book-to-market, and 1-year lag cumulative return at the end of the previous year, respectively. Technically, we adopted the 2x3 configuration developed by Faff (2004) and Qoyum et al. (2020). All portfolio returns were calculated on value-weighted terms based on the previous year's market cap.

4FFC is an asset-pricing model developed from the capital asset pricing model (CAPM), Fama-French three-factor model, and momentum factor. Sharpe (1964), Lintner (1965) and Jensen (1968) assumed that the market portfolio is meanvariance efficient, and initiated CAPM to value the risk-adjusted return of an asset or portfolio. Fama and French (1996) promoted three factors (3FF), market, size, and value, on the asset pricing model. Carhart (1997) also proposed momentum as an additional factor for the 3FF. Some empirical works have suggested that $4 \mathrm{FFC}$ outperforms CAPM in explaining an asset of portfolio price (Grauer \& Janmaat, 2010; Mateus et al., 2019), especially in Indonesia (Qoyum et al., 2020).

\subsection{Method}

As explained in the model development, we adopted the Fama-MathBeth approach modified by Seok et al. (2019a). In our method, there are two ways to test the difference in sentiment-based mispricing between Islamic stocks and their non- 
Islamic counterparts, namely in interaction and split-sample form. The first can be expressed in equation (3) as follows:

$$
\begin{aligned}
& \operatorname{RET}_{i t}=\beta_{0}+\beta_{1} \text { SENT }_{i t}+\beta_{2} \text { IS }_{i}+\beta_{3} \text { SENT }_{i t} \times I_{i}+\sum_{j=1}^{4} \theta_{j} F F C C_{j, t}+\varepsilon_{i t} \\
& \operatorname{RET}_{i t}=\beta_{0}+\beta_{1} \operatorname{SENT}_{i t}+\sum_{j=1}^{4} \theta_{j} F C_{j, t}+\varepsilon_{i t}
\end{aligned}
$$

where $\mathrm{RET}_{\mathrm{it}}$ is daily stock return; $\mathrm{SENT}_{\mathrm{it}}$ represents the composite sentiment index; $\mathrm{IS}_{\mathrm{i}}$ is an Islamic dummy equal to 1 if the firms are sharia-compliant; $\mathrm{FFC}_{\mathrm{j}, \mathrm{t}}$ consists of MKT, SMB, HML, and UMD; and $\varepsilon_{\mathrm{it}}$ is the error term.

$\beta_{1}$ in equation (3) is expected to be positively significant so as firm-specific sentiment is positively associated with stock return. If investors are overly confident in a company's prospects, then the stock price will increase above its fundamental value, or vice versa. The effect of Islamic values on sentiment-based mispricing can be identified on $\beta_{3}$ (equation 3). Since we hypothesise that the presence of Islamic value will reduce sentiment-based mispricing, $\beta_{3}$ is expected to be negatively significant. In other words, sharia-compliant stock is less exposed to sentiment-based mispricing. In the second method, we estimated equation (4) for Islamic stocks and non-Islamic stocks separately, and then the $\beta_{1}$ values (equation 4 ) of both groups were compared. If the $\beta_{1}$ of Islamic stocks is lower than that of non-Islamic stocks, we have the same interpretation as in the first method.

In estimating the equations, Seok et al. (2019a) suggested pooled least squares (PLS), although the method has some limitations. It ignores heterogeneity, since the issue is critical in pooled data with large $i$ (cross-section) and $t$ (time series) dimensions (Pesaran, 2015). A heterogeneous intercept can be controlled by adding a fixed effect or within an estimator (Wooldridge, 2018). Equation (4) can then be estimated by the fixed-effect model (FEM). However, there is an exception in equation (3). If FEM is used to calculate this equation, the time-invariant factor, the Islamic dummy (IS), will be wiped out. Moreover, there is a potential for endogeneity between the sentiment index $\left(\mathrm{SENT}_{\mathrm{it}}\right)$ and its interaction variable $\left(\mathrm{SENT}_{\mathrm{it}} \times \mathrm{IS}_{\mathrm{i}}\right)$.

Considering some of the estimation issues, we estimated equation (3) using the Hausman-Taylor (H-T) approach for the error-components model (Baltagi \& Liu, 2012; Hausman \& Taylor, 1981). Some empirical studies have used H-T regression to recapture time-invariant variable estimates and to deal with endogeneity (Dixit \& Pal, 2010; Ibrahim, 2020; McPherson \& Trumbull, 2008). Furthermore, stationarity is essential for time series and panel analysis with long $t$ (Choi, 2001; Maddala \& $\mathrm{Wu}, 1999)$. The non-fulfilment of the assumption leads to spurious parameters. We then conducted the unit root test employing the Fisher-type (panel) and Augmented Dickey-Fuller (time series) tests. 


\section{RESULTS AND ANALYSIS}

In this section, we present the descriptive statistics, baseline and robustness analysis, and discussion.

\subsection{Results}

\subsubsection{Statistic Descriptive}

Tables 6 and 7 show the statistic descriptive and matrix correlation. The expected daily return (RET) of Islamic stock (I.S.) merely is higher than that of its nonIslamic counterpart (NIS). Likewise, on average, Islamic stocks have higher firmspecific sentiment (SENT) than their non-Islamic counterparts. However, this simple comparison must be confirmed by controlling certain factors that explain cross-sectional characteristics. Based on the panel and time-series unit root tests, all the variables are stationary at a level that indicates no spurious parameters.

Table 6.

Statistic Descriptive

\begin{tabular}{lcccccc}
\hline Variable & Obs. & Mean & SD & Min. & Max. & Unit root \\
\hline RET & 344,694 & 0.016 & 3.040 & -120.400 & 33.020 & $499.290^{* * *}$ \\
\multicolumn{1}{r}{ IS } & 178,290 & 0.023 & 2.953 & -36.357 & 30.010 & $359.090^{* * *}$ \\
\multicolumn{1}{r}{ NIS } & 166,404 & 0.010 & 3.130 & -120.400 & 33.020 & $346.910^{* * *}$ \\
SENT & 249,707 & 2.250 & 19.673 & -165.200 & 144.330 & $242.360^{* * *}$ \\
\multicolumn{1}{l}{ IS } & 132,688 & 2.801 & 19.615 & -165.200 & 99.390 & $186.360^{* * *}$ \\
\multicolumn{1}{r}{ NIS } & 117,019 & 1.624 & 19.721 & -91.040 & 144.330 & $155.920^{* * *}$ \\
MKT & 344,694 & 0.013 & 0.967 & -5.766 & 4.524 & $-29.750^{* * *}$ \\
SMB & 344,694 & -0.006 & 0.773 & -3.379 & 2.742 & $-29.810^{* * *}$ \\
HML & 344,694 & 0.004 & 0.748 & -3.142 & 3.297 & $-28.770^{* * *}$ \\
UMD & 344,694 & 0.017 & 0.797 & -4.893 & 3.136 & $-29.160^{* * *}$ \\
\hline
\end{tabular}

This table shows the statistic descriptive information, which comprises the number of observations, mean, standard deviation, minimum, and maximum. It also includes the unit root test to check the stationary condition. We divided the panel unit root (RET and SENT) and time series unit root (MKT, SMB, HML, and UMD). The parameter of the panel unit root was a modified inverse $\chi^{2}$ (chi-square), whereas the time-series unit root was represented by Augmented Dickey-Fuller statistics (ADF Stat.). The null hypothesis for the time-series unit root test was that a unit root or nonstationary condition exists. IS and NIS denote Islamic stocks and their non-Islamic counterparts respectively. ${ }^{*}$; ${ }^{* *}$;** denote significance at $10 \%, 5 \%$, and $1 \%$ respectively .

As shown in Table 6, the correlation magnitude of SENT-RET and MKTRET is almost the same, and significant at the $1 \%$ level. This explains that firmspecific sentiment has the potential to be as essential as a market risk premium in explaining cross-sectional returns. Hence, further analysis needs to be conducted to confirm our matrix correlation. 
Table 7.

Matrix Correlation

\begin{tabular}{lcccccc}
\hline & RET & SENT & MKT & SMB & HML & UMD \\
\hline RET & 1.000 & & & & & \\
SENT & $0.276^{* * *}$ & 1.000 & & & & \\
MKT & $0.221^{* * *}$ & $0.023^{* * *}$ & 1.000 & & & \\
SMB & $0.065^{* * *}$ & $0.061^{* * *}$ & $-0.619^{* * *}$ & 1.000 & & \\
HML & $0.049^{* * *}$ & $0.064^{* * *}$ & $-0.004^{* *}$ & $0.187^{* * *}$ & 1.000 & \\
UMD & $-0.007^{* * *}$ & $-0.016^{* * *}$ & $0.024^{* * *}$ & $0.007^{* * *}$ & $-0.141^{* * *}$ & 1.000 \\
\hline$* ; * * * * *$ & & &
\end{tabular}

\subsubsection{Hausman-Taylor Regression Results}

Table 8 shows the baseline Fama-MacBeth regression. Columns (1) to (3) include the estimated parameter (coefficients and t-statistics) for the interaction regression. In addition, columns (4) and (5) show the split-sample analysis, in which the effect of firm-specific sentiment on return is divided into NIS and I.S. groups respectively. As the F-stat parameters are significant at $1 \%$, our baseline results are well specified. First, we discuss the interaction regression. The coefficients of $\mathrm{SENT}_{\text {it }}$ on the three regression models (CAPM, FF, and FFC) are positively significant. Therefore, the higher the firm-specific sentiment, the higher the stock returns will be. When investors are overconfident in their stock appraisal, its price will deviate from its fundamental value.

Contrary to our descriptive statistics, the coefficients of $\mathrm{IS}_{\mathrm{i}}$ are negatively significant. By accounting for sentiment and risk factors in our asset pricing models, the Islamic stock daily return is lower than that of its non-Islamic counterpart. The interaction term $\left(\mathrm{SENT}_{\mathrm{it}} \times \mathrm{IS}_{\mathrm{i}}\right)$ has significantly negative coefficients for all the asset pricing models (CAPM, FF, and FFC). The results indicate that Islamic values negatively moderate the effect of firm-specific sentiment on stock return. In other words, Islamic stocks are less exposed to sentiment-based mispricing than nonIslamic ones.

Second, Columns (4) and (5) show the baseline split-sample regression. NIS and IS represent non-Islamic stocks and Islamic stocks respectively. SENT is positively significant in both groups, but its magnitude on IS regression is relatively lower. Therefore, Islamic stocks are less mispriced than non-Islamic ones. Overall, the interaction and split-sample approach in our analysis leads to similar implications. 
Table 8.

Baseline Fama-MacBeth Regression Analysis

\begin{tabular}{|c|c|c|c|c|c|}
\hline & \multicolumn{3}{|c|}{ FULL SAMPLE } & \multirow{2}{*}{$\begin{array}{c}\text { NIS } \\
(4)\end{array}$} & \multirow{2}{*}{$\begin{array}{l}\text { IS } \\
\text { (5) }\end{array}$} \\
\hline & (1) & (2) & (3) & & \\
\hline \multirow[t]{2}{*}{$\overline{\mathrm{SENT}_{\text {it }}}$} & $0.054^{* * *}$ & $0.053^{* * *}$ & $0.053^{* * *}$ & $0.053^{* * *}$ & $0.046^{* * *}$ \\
\hline & (21.390) & $(21.160)$ & $(21.150)$ & $(21.410)$ & $(22.880)$ \\
\hline \multirow[t]{2}{*}{$\mathrm{IS}_{\mathrm{i}}$} & $-0.052^{* *}$ & $-0.049^{* *}$ & $-0.049^{* *}$ & & \\
\hline & $(-2.090)$ & $(-1.990)$ & $(-1.990)$ & & \\
\hline \multirow{2}{*}{$\operatorname{SENT}_{\mathrm{it}} \times \mathrm{IS}_{\mathrm{i}}$} & $-0.007^{* *}$ & $-0.007^{* *}$ & $-0.007^{* *}$ & & \\
\hline & $(-2.150)$ & $(-2.190)$ & $(-2.200)$ & & \\
\hline \multirow{2}{*}{$\mathrm{MKT}_{\mathrm{it}}$} & $0.880^{* * *}$ & $1.076^{* * *}$ & $1.079^{* * *}$ & $1.022^{* * *}$ & $1.129^{* * *}$ \\
\hline & $(36.170)$ & $(41.800)$ & $(41.870)$ & $(29.700)$ & $(30.350)$ \\
\hline \multirow[t]{2}{*}{$\mathrm{SMB}_{\mathrm{t}}$} & & $0.405^{* * *}$ & $0.408^{* * *}$ & $0.412^{* * *}$ & $0.405^{* * *}$ \\
\hline & & $(12.600)$ & $(12.750)$ & $(8.610)$ & $(9.380)$ \\
\hline \multirow[t]{2}{*}{$\mathrm{HML}_{\mathrm{t}}$} & & $0.106^{* * *}$ & $0.099 * * *$ & $0.159^{* * *}$ & 0.046 \\
\hline & & $(4.280)$ & $(4.070)$ & $(4.020)$ & $(1.600)$ \\
\hline \multirow[t]{2}{*}{$\mathrm{UMD}_{\mathrm{t}}$} & & & $-0.041^{* *}$ & -0.022 & $-0.058^{* *}$ \\
\hline & & & $(-2.450)$ & $(-0.950)$ & $(-2.440)$ \\
\hline \multirow[t]{2}{*}{ C } & $-0.047^{* *}$ & $-0.044^{* *}$ & $-0.043^{* *}$ & $-0.071^{* * *}$ & $-0.100^{* * *}$ \\
\hline & $(-2.240)$ & $(-2.170)$ & $(-2.130)$ & $(-18.010)$ & $(-18.440)$ \\
\hline Obs. & 249,707 & 249,707 & 249,707 & 117,019 & 132,688 \\
\hline Firms & 203 & 203 & 203 & 98 & 105 \\
\hline $\mathrm{F}$ (Stat.) & $913.46^{* * *}$ & $623.91^{* * *}$ & $535.82^{* * *}$ & $387.43^{* * *}$ & $400.39^{* * *}$ \\
\hline
\end{tabular}

Table 8 shows the primary regression analysis, in which an explained variable is the excess return of stock $\mathrm{i}$ on day $\mathrm{t}\left(\operatorname{EXR}_{\mathrm{it}}\right)$. We estimated the full-sample model (Columns 1-3) by the Hausman-Taylor method and the splitsample model (Columns 4-5) by the least squares dummy variable (LSDV) method. NIS and IS signify non-Islamic and Islamic respectively. The robust standard error is clustered at the firm level to relax heteroscedasticity and autocorrelation within the panel. The goodness-of-fit test is joint parameters' significance shown in the value of the F-statistics (F-stat.). The T-statistics are in parentheses . *; ${ }^{* *}$ and ${ }^{* * *}$ indicate significance at levels of 1\%, 5\%, and $10 \%$ respectively .

\subsection{Robustness Test}

Some issues are highlighted in stock or portfolio valuation. First, industry characteristics may explain why the effect of firm-specific sentiment on stock return varies cross-sectionally (Bannigidadmath, 2020; Chen et al., 2013; Huang et al., 2015). Moreover, our sample setting shows that no Islamic stock is listed in the financial sector. Therefore, we conducted split-sample regression based on type of industry to deal with industry-specific characteristics.

As in our baseline analysis, the F-stat values in the industry-based (Table 9) and FFC-portfolio (Table 10) regressions are significant at $1 \%$. The effect of firmspecific sentiment on stock return across sectors remains consistent, while the coefficients of IS ${ }_{\mathrm{i}}$ are insignificant across sectors. At the industry level, we did not find any critical differences between Islamic and non-Islamic stocks. Meanwhile, the magnitude of $\mathrm{SENT}_{\mathrm{it}} \times \mathrm{IS}_{\mathrm{i}}$ are heterogeneous and only insignificant in the basic and chemical (BIC), consumer goods (CGI), and miscellaneous (MIC) industries. Hence, we conclude that Islamic values reduce sentiment-based mispricing in the majority of industries. 
Table 9.

Regression Grouped by Industry Classification

\begin{tabular}{lccccccc}
\hline & SENT $_{\text {it }}$ & IS $_{i}$ & SENT $_{\text {it }}$ IS & C & Obs. & Firms & F(Stat.) \\
\hline AG & $0.055^{* * *}$ & -0.107 & $-0.023^{* *}$ & -0.006 & 11,611 & 9 & $36.60^{* * *}$ \\
& $(5.71)$ & $(-0.96)$ & $(-2.32)$ & $(-0.05)$ & & & \\
BIC & $0.050^{* * *}$ & 0.033 & 0.002 & $-0.128^{* * *}$ & 40,001 & 34 & $115.03^{* * *}$ \\
& $(8.98)$ & $(0.67)$ & $(0.27)$ & $(-3.22)$ & & & \\
\multirow{2}{*}{ CGI } & $0.042^{* * *}$ & -0.078 & -0.000 & 0.034 & 27,346 & 21 & $632.93^{* * *}$ \\
& $(27.15)$ & $(-1.15)$ & $(-0.00)$ & $(0.60)$ & & & \\
\multirow{2}{*}{ IUT } & $0.052^{* * *}$ & -0.011 & $-0.011^{* * *}$ & -0.058 & 20,014 & 16 & $473.04^{* * *}$ \\
& $(38.48)$ & $(-0.10)$ & $(-3.45)$ & $(-1.21)$ & & & \\
\multirow{2}{*}{ MIN } & $0.061^{* * *}$ & -0.022 & $-0.024^{* * *}$ & $-0.151^{* * *}$ & 25,823 & 19 & $928.85^{* * *}$ \\
& $(42.00)$ & $(-0.40)$ & $(-11.93)$ & $(-3.84)$ & & & \\
\multirow{2}{*}{ MIC } & $0.056^{* * *}$ & 0.045 & -0.005 & -0.105 & 17,523 & 14 & $328.05^{* * *}$ \\
\multirow{2}{*}{ PRB } & $(21.07)$ & $(0.49)$ & $(-1.51)$ & $(-1.35)$ & & & \\
& $0.066^{* * *}$ & 0.027 & $-0.026^{* * *}$ & $-0.159^{* *}$ & 35,951 & 28 & $1353.4^{* * *}$ \\
\multirow{2}{*}{ TSI } & $(33.50)$ & $(0.37)$ & $(-12.10)$ & $(-2.45)$ & & & \\
& $0.058^{* * *}$ & -0.057 & $-0.006^{* * *}$ & 0.041 & 47,961 & 43 & $944.13^{* * *}$ \\
& $(45.64)$ & $(-0.75)$ & $(-3.61)$ & $(0.75)$ & & & \\
\hline
\end{tabular}

This table shows the estimated parameters based on industry characteristics. The industries are agriculture (AGR); basic industry and basic industry and chemicals (BIC); consumer goods industry (CGI); infrastructure, utilities and transportation (IUT); mining (MIN); miscellaneous industries (MIC); property, real estate, and building construction (PRB); and trade, services and investment (TSI). As it contains no Islamic firms, the financial industry (FIN) is excluded. Each of the equations includes the Fama-French-Carhart model and is estimated by the Hausman-Taylor method. The goodness-of-fit test is joint parameters' significance is shown by the value of the F-statistics (F-stat.). The T-statistics are shown in parentheses. ${ }^{*}{ }^{* *} ;{ }^{* *}$ indicate significance at the $1 \%, 5 \%$, and $10 \%$ levels respectively.

Apart from testing the robustness of the results across industries, we also conducted a split-sample based on 4FFC portfolios. This was inspired by the findings of Huang et al. (2015), Stambaugh and Yuan (2017), and Qadan and Aharon (2019), that sentiment-risk exposures are diverse across size, value, and momentum portfolios. We then split our analysis built upon the FamaFrench-Carhart portfolio and show the results in Table 10. Firm-specific investor sentiment positively effects stock return across the portfolios, although we did find a minor anomaly in the small size portfolio. In the small-high (S.H.) portfolio, sharia-compliant stocks were more exposed to mispricing than their non-Islamic counterparts. Moreover, the interaction effect was insignificant in the small-down (S.D.) portfolio. Notwithstanding this, it can be summarised that Islamic values reduce sentiment-based mispricing across the Fama-French-Carhart portfolios. Concerning our baseline and robustness analysis, it was proven that Islamic values markedly reduce the mispricing effect. 
Table 10.

Regression Grouped by The Fama-French-Carhart Portfolio

\begin{tabular}{|c|c|c|c|c|c|c|c|}
\hline & SENT $_{\text {it }}$ & IS $_{i}$ & SENT $_{i+} \times$ IS $_{i}$ & $\mathrm{C}$ & Obs. & Firms & F(Stat.) \\
\hline \multicolumn{8}{|c|}{ Panel A: SIZE-VALUE } \\
\hline SL & $\begin{array}{c}0.059^{* * *} \\
(38.00)\end{array}$ & $\begin{array}{l}0.018 \\
(0.29)\end{array}$ & $\begin{array}{c}-0.010^{* * * *} \\
(-4.83)\end{array}$ & $\begin{array}{l}0.012 \\
(0.27)\end{array}$ & 34,383 & 68 & $726.57^{* * *}$ \\
\hline $\mathrm{SH}$ & $\begin{array}{c}0.067^{* * *} \\
(44.27)\end{array}$ & $\begin{array}{l}-0.040 \\
(-0.51)\end{array}$ & $\begin{array}{c}0.007^{* * *} \\
(-2.78)\end{array}$ & $\begin{array}{c}-0.199^{* * * *} \\
(-3.93)\end{array}$ & 33,710 & 66 & $827.92^{* * *}$ \\
\hline BL & $\begin{array}{c}0.039^{* * *} \\
(38.10)\end{array}$ & $\begin{array}{l}-0.099 \\
(-1.59)\end{array}$ & $\begin{array}{c}-0.007^{* * *} \\
(-5.20)\end{array}$ & $\begin{array}{l}-0.005 \\
(-0.11)\end{array}$ & 41,120 & 58 & $1313.18^{* * *}$ \\
\hline $\mathrm{BH}$ & $\begin{array}{c}0.042^{* * *} \\
(46.02)\end{array}$ & $\begin{array}{l}-0.005 \\
(-0.13) \\
\end{array}$ & $\begin{array}{c}-0.006^{* * *} \\
(-4.33) \\
\end{array}$ & $\begin{array}{c}-0.103^{* * *} \\
(-3.78)\end{array}$ & 39,068 & 56 & $1365.27^{* * *}$ \\
\hline \multicolumn{8}{|c|}{ Panel B: SIZE-MOMENTUM } \\
\hline SD & $\begin{array}{l}0.065^{* * *} \\
(39.810)\end{array}$ & $\begin{array}{c}0.031 \\
(0.535)\end{array}$ & $\begin{array}{c}-0.002 \\
(-0.882)\end{array}$ & $\begin{array}{c}-0.090^{* *} \\
(-2.180)\end{array}$ & 35,016 & 110 & $830.02^{* * *}$ \\
\hline SU & $\begin{array}{l}0.066^{* * *} \\
(41.330)\end{array}$ & $\begin{array}{c}0.035 \\
(0.530)\end{array}$ & $\begin{array}{l}-0.006^{* *} \\
(-2.563)\end{array}$ & $\begin{array}{l}-0.054 \\
(-1.160)\end{array}$ & 33,718 & 97 & $817.55^{* * *}$ \\
\hline $\mathrm{BD}$ & $\begin{array}{l}0.040^{* * *} \\
(43.300)\end{array}$ & $\begin{array}{l}-0.050 \\
(-1.641)\end{array}$ & $\begin{array}{c}-0.006^{* * *} \\
(-4.512)\end{array}$ & $\begin{array}{c}-0.077^{* * *} \\
(-3.620)\end{array}$ & 41,346 & 95 & $1414.65^{* * *}$ \\
\hline $\mathrm{BU}$ & $\begin{array}{l}0.039^{* * *} \\
(44.150)\end{array}$ & $\begin{array}{c}-0.019 \\
(-0.465)\end{array}$ & $\begin{array}{c}-0.007^{* * * *} \\
(-6.038)\end{array}$ & $\begin{array}{l}-0.074^{* *} \\
(-2.470)\end{array}$ & 55,248 & 102 & $1495.33^{* * *}$ \\
\hline
\end{tabular}

This table shows the estimated parameters based on the Fama-French (2012) portfolios. Panel A consists of sizevalue portfolios constructed by market capitalisation and the book-to-market ratio each year, while Panel B comprises the size-momentum portfolios constructed by market capitalisation and momentum. Each of the equations includes Fama-French-Carhart factors (MKT, SMB, HML, and UMD) and is estimated by the Hausman-Taylor method. The goodness-of-fit test is joint parameters' significance shown at the value of the F-statistics (F-stat.). T-statistics are shown in parentheses . ${ }^{* * *}$ and ${ }^{* * *}$ indicate significance at the $1 \%, 5 \%$, and $10 \%$ levels respectively .

\subsection{Analysis}

With respect to our ultimate objective, we first tested the effect of firm-specific investor sentiment on cross-sectional stock returns. Using the Fama-MacBeth approach, our baseline and robustness analysis showed that investor sentiment was positively associated with stock return. This finding is supported by previous studies which explain that in a contemporaneous period, the higher positive investor sentiment becomes, the higher the stock return will be, or vice versa (Ryu et al., 2017; Seok et al., 2019a; Spyrou, 2012). Therefore, high investor sentiment will move equity prices away from their intrinsic value.

Second, we tested the interaction term of the Islamic dummy and firm-specific investor sentiment and conducted split-sample regression. Overall, the results demonstrate that the level of sentiment of the sharia-compliant stock is lower than that of its non-Islamic counterpart. This is in line with our previous studies that both Islamic or non-Islamic equities are affected by investor sentiment and become mispriced (Perez-Liston et al., 2016). However, Islamic ones are less exposed to sentiment-based mispricing (Dash \& Maitra, 2018).

On the contrary, Aloui et al. (2016) clarify that the prohibition of non-ethical, uncertain, and speculative business, interest-bearing transaction (riba), and excessive leverage contribute to making equity prices fairer. In addition, as we 
adopted firm-level sentiment, in which common factors are replaced, it may differ from the findings of Aloui et al. (2016), and Perez-Liston et al. (2016).

\section{CONCLUSION AND RECOMMENDATIONS}

\subsection{Conclusion}

Investor sentiment is one of the mispricing factors that create noise price in equity. Because investors overestimate new information compared to fundamental information, stock prices deviate from their intrinsic value. Empirically, mispricing can be identified by investigating sentiment-return relations. Some studies have confirmed that investor sentiment is a powerful predictor. However, Islamic values adopted to establish sharia-compliant stocks may reduce the effect of sentiment on stock return. Therefore, our study has aimed to investigate the effect of investor sentiment on stock return. Furthermore, we examined the role of Islamic values in shaping the sentiment-return link.

In conclusion, mispricing occurs with both Islamic or non-Islamic stocks. Hence, both types of stock could be exposed by mispricing. Second, Islamic stocks are less exposed to sentiment-based mispricing than non-Islamic ones. The reason behind this phenomenon is that Islamic values, such as the prohibition of interest, speculative and uncertain transactions, and excessive leverage, arguably reduce sentiment-based mispricing.

Third, our findings are consistent with our robustness test, in which we estimated the equation model across industries and portfolios. Therefore, Islamic stocks are steadier than conventional ones in maintaining their price in the face of exposure to mispricing. Finally, our conclusions imply the strength of Islamic stocks in Indonesia.

\subsection{Recommendations}

This section consists of recommendations for both investors and regulators based on the findings of the study. It is vital for investors to consider their investment in Islamic stocks, especially local investors, and to be extended for more comprehensive investors worldwide.

First, sensitivity to sentiment exposure signifies stock price stability. As our findings confirm the lower exposure of Islamic stock, portfolios composed of such stocks will yield more stable returns compared to conventional stocks. Therefore, Islamic portfolios are recommended for long-term investors. Second, the rules regarding the mechanism of Islamic equity trading are included in the fatwa of the National Sharia Board (Number: 80/DSN-MUI/II/2011), some of which prohibit manipulation of demand by utilising noise information. Based on our work, the fatwa is quite effective in reducing sentiment-based mispricing of Islamic stocks. Moreover, policymakers should strengthen the implementation of Islamic values to enhance the efficiency of the equity market. In future studies, we suggest enhancing the analysis by including inter-temporal firm-specific investor sentiment to explore price adjustment mechanisms. 


\section{REFERENCES}

Ackert, L., \& Deaves, R. (2010). Behavioral finance: Psychology, decision-making, and markets. Boston: Cengage Learning.

Adam, N. L., \& Bakar, N. A. (2014). Shariah screening process in Malaysia. Procedia - Social and Behavioral Sciences, 121, 113-123. https://doi.org/10.1016/j. sbspro.2014.01.1113

Aggarwal, D. (2019). Defining and measuring market sentiments: A review of the literature. Qualitative Research in Financial Markets. https://doi.org/10.1108/ QRFM-03-2018-0033

Ahmed, W. M. A. (2018). How do Islamic versus conventional equity markets react to political risk? Dynamic panel evidence. International Economics, 156(November 2017), 284-304. https://doi.org/10.1016/j.inteco.2018.05.001

Ahmed, W. M. A. (2020). Stock market reactions to domestic sentiment: Panel CSARDL evidence. Research in International Business and Finance, 54(May), 101240. https://doi.org/10.1016/j.ribaf.2020.101240

Al-Khazali, O., Lean, H. H., \& Samet, A. (2014). Do Islamic stock indexes outperform conventional stock indexes? A stochastic dominance approach. Pacific-Basin Finance Journal, 28, 29-46. https://doi.org/10.1016/j.pacfin.2013.09.003

Alam, M., \& Ansari, V. A. (2020). Are Islamic indices a viable investment avenue? An empirical study of Islamic and conventional indices in India. International Journal of Islamic and Middle Eastern Finance and Management, 13(3), 503-518. https://doi.org/10.1108/IMEFM-03-2019-0121

Allen, D. E., McAleer, M., \& Singh, A. K. (2019). Daily market news sentiment and stock prices. Applied Economics, 51(30), 3212-3235. https://doi.org/10.1080/0003 6846.2018.1564115

Aloui, C., Hkiri, B., Lau, C. K. M., \& Yarovaya, L. (2016). Investors' sentiment and US Islamic and conventional indexes nexus: A time-frequency analysis. Finance Research Letters, 19, 54-59. https://doi.org/10.1016/j.frl.2016.06.002

Amihud, Y. (2002). Illiquidity and stock returns: Cross-section and time-series effects. Journal of Financial Markets, 5(1), 31-56. https://doi.org/10.1016/S13864181(01)00024-6

Anusakumar, S. V., Ali, R., \& Wooi, H. C. (2017). The effect of investor sentiment on stock returns: Insight from emerging Asian markets. Asian Academy of Management Journal of Accounting and Finance, 13(1), 159-178. https://doi. org/10.21315/aamjaf2017.13.1.7

Ashraf, D. (2016). Does shari'ah screening cause abnormal returns? Empirical evidence from Islamic equity indices. Journal of Business Ethics, 134(2), 209-228. https://doi.org/10.1007/s10551-014-2422-2

Azmi, W., Ng, A., Dewandaru, G., \& Nagayev, R. (2019). Doing well while doing good: The case of Islamic and sustainability equity investing. Borsa Istanbul Review, 19(3), 207-218. https://doi.org/10.1016/j.bir.2019.02.002

Baker, M., \& Stein, J. C. (2004). Market liquidity as a sentiment indicator. Journal of Financial Markets, 7(3), 271-299. https://doi.org/10.1016/j.finmar.2003.11.005

Baker, M., \& Wurgler, J. (2006). Investor sentiment and the cross-section of stock returns. Journal of Finance, 61(4), 1645-1680. https://doi.org/10.1111/j.15406261.2006.00885.x

Baker, M., \& Wurgler, J. (2007). Investor sentiment in the stock market. Journal of Economic Perspectives, 21(2), 129-151. https://doi.org/10.1257/jep.21.2.129 
Baker, M., Wurgler, J., \& Yuan, Y. (2012). Global, local, and contagious investor sentiment. Journal of Financial Economics, 104(2), 272-287. https://doi. org/10.1016/j.jfineco.2011.11.002

Baltagi, B. H., \& Liu, L. (2012). The Hausman-Taylor panel data model with serial correlation. Statistics and Probability Letters, 82(7), 1401-1406. https://doi. org/10.1016/j.spl.2012.03.016

Bannigidadmath, D. (2020). Consumer sentiment and Indonesia's stock returns. Buletin Ekonomi Moneter dan Perbankan, 23, 1-12. https://doi.org/10.21098/ bemp.v23i0.1194

Barber, B. M., Odean, T., \& Zhu, N. (2009). Systematic noise. Journal of Financial Markets, 12(4), 547-569. https://doi.org/10.1016/j.finmar.2009.03.003

Barberis, N., \& Thaler, R. (2002). A survey of behavioral finance. http://www.nber. org/papers/w9222.

Bennett, M. S., \& Iqbal, Z. (2013). How socially responsible investing can help bridge the gap between Islamic and conventional financial markets. International Journal of Islamic and Middle Eastern Finance and Management, 6(3), 211-225. https://doi.org/10.1108/IMEFM-Aug-2012-0078

Berberis, Nicholas, Shleifer, A., \& Vishny, R. (1996). Improved methods for tests of long-run abnormal returns. CRSP Working Paper 443, Graduate School of Business, University of Chicago.

Black, F. (1986). Noise. The Journal of Finance, 41(3), 528-543. https://doi. org/10.1111/j.1540-6261.1986.tb04513.x

Bloomfield, R., O'Hara, M., \& Saar, G. (2009). How noise trading affects markets: An experimental analysis. Review of Financial Studies, 22(6), 2275-2302. https:// doi.org/10.1093/rfs/hhn102

Bodie, Z., Kane, A., \& Marcus, A. J. (2014). Investments (10th Ed). McGraw-Hill Education.

Brown, G. W., \& Cliff, M. T. (2004). Investor sentiment and the near-term stock market. Journal of Empirical Finance, 11(1), 1-27. https://doi.org/10.1016/j. jempfin.2002.12.001

Cagli, E. C., Can Ergün, Z., \& Durukan, M. B. (2020). The causal linkages between investor sentiment and excess returns on Borsa Istanbul. Borsa Istanbul Review, 20(3), 214-223. https://doi.org/10.1016/j.bir.2020.02.001

Carhart, M. M. (1997). On persistence in mutual fund performance. The Journal of Finance, 52(1), 57-82. https://www.jstor.org/stable/2329556

Chen, M. P., Chen, P. F., \& Lee, C. C. (2013). Asymmetric effects of investor sentiment on industry stock returns: Panel data evidence. Emerging Markets Review, 14(1), 35-54. https://doi.org/10.1016/j.ememar.2012.11.001

Choi, I. (2001). Unit root tests for panel data. Journal of International Money and Finance, 20(2), 249-272. https://doi.org/10.1016/S0261-5606(00)00048-6

Chong, T. T. L., \& Ng, W. K. (2008). Technical analysis and the London stock exchange: Testing the MACD and RSI rules using the FT30. Applied Economics Letters, 15(14), 1111-1114. https://doi.org/10.1080/13504850600993598

Corredor, P., Ferrer, E., \& Santamaria, R. (2013). Investor sentiment effect in stock markets: Stock characteristics or country-specific factors? International Review of Economics and Finance, 27, 572-591. https://doi.org/10.1016/j.iref.2013.02.001

Cui, H., \& Zhang, Y. (2019). Does investor sentiment affect stock price crash risk? Applied Economics Letters, 27(7), 564-568. https://doi.org/10.1080/13504851.201 


\subsection{8}

Dai, Z. M., \& Yang, D. C. (2018). Positive feedback trading and investor sentiment. Emerging Markets Finance and Trade, 54(10), 2400-2408. https://doi.org/10.1080/ 1540496X.2018.1469003

Dash, S. R., \& Maitra, D. (2018). Does shariah index hedge against sentiment risk? Evidence from Indian stock market using time-frequency domain approach. Journal of Behavioral and Experimental Finance, 19, 20-35. https://doi.org/10.1016/j. jbef.2018.03.003

Dharani, M., Hassan, M. K., \& Paltrinieri, A. (2019). Faith-based norms and portfolio performance: Evidence from India. Global Finance Journal, 41(February), 79-89. https://doi.org/10.1016/j.gfj.2019.02.001

Dixit, K., \& Pal, R. (2010). The impact of group incentives on performance of small firms: Hausman-taylor estimates. Managerial and Decision Economics, 31(6), 403-414. https://doi.org/10.1002/mde.1494

Erdogan, S., Gedikli, A., \& Çevik, E. İ. (2020). Volatility Spillover Effects Between Islamic Stock Markets And Exchange Rates: Evidence From Three Emerging Countries. Borsa Istanbul Review, 20(4), 322-333. https://doi.org/10.1016/j. bir.2020.04.003

Faff, R. (2004). A simple test of the Fama and French model using daily data: Australian evidence. Applied Financial Economics, 14(2), 83-92. https://doi. org/10.1080/0960310042000176353

Fama, E. F. (1991). Efficient capital markets: II. The Journal of Finance, 46(5), 1575. https://doi.org/10.2307/2328565

Fama, E. F., \& French, K. (1996). Multifactor explanations of asset pricing anomalies. The Journal of Finance, 51(1), 55-84.

Fama, E. F., \& French, K. R. (1992). The cross-section of expected stock returns. The Journal of Finance, 68(2), 427-465.

Fama, E. F., \& French, K. R. (2012). Size, value, and momentum in international stock returns. Journal of Financial Economics, 105(3), 457-472. https://doi. org/10.1016/j.jfineco.2012.05.011

Fama, E. F., \& MacBeth, J. D. (1973). Risk, return, and equilibrium: Empirical tests. Journal of Political Economy, 81(3), 607-636.

Filbeck, G., Ricciardi, V., Evensky, H. R., Fan, S. Z., Holzhauer, H. M., \& Spieler, A. (2017). Behavioral finance: A panel discussion. Journal of Behavioral and Experimental Finance, 15, 52-58. https://doi.org/10.1016/j.jbef.2017.07.008

French, J. J., \& Li, W. X. (2017). Sentiment, foreign equity flows, and returns: Evidence from Thailand's stock markets. Research in International Business and Finance, 42(October 2016), 816-831. https://doi.org/10.1016/j.ribaf.2017.07.018

Fu, J., Wu, X., Liu, Y., \& Chen, R. (2020). Firm-specific investor sentiment and stock price crash risk. Finance Research Letters, January, 101442. https://doi. org/10.1016/j.frl.2020.101442

Fu, J., Zhou, Q., Liu, Y., \& Wu, X. (2020). Predicting stock market crises using daily stock market valuation and investor sentiment indicators. North American Journal of Economics and Finance, 51(18), 100905. https://doi.org/10.1016/j. najef.2019.01.002

Galema, R., Plantinga, A., \& Scholtens, B. (2008). The stocks at stake: Return and risk in socially responsible investment. Journal of Banking and Finance, 32(12), 
2646-2654. https://doi.org/10.1016/j.jbankfin.2008.06.002

Glaser, M., Nöth, M., \& Weber, M. (2004). Applications Behavioral Finance. Blackwell Handbook of Judgement and Decision Making.

Grauer, R. R., \& Janmaat, J. A. (2010). Cross-sectional tests of the CAPM and Fama-French three-factor model. Journal of Banking and Finance, 34(2), 457-470. https://doi.org/10.1016/j.jbankfin.2009.08.011

Gupta, R., Risse, M., Volkman, D. A., \& Wohar, M. E. (2019). The role of term spread and pattern changes in predicting stock returns and volatility of the United Kingdom: Evidence from a nonparametric causality-in-quantiles test using over 250 years of data. North American Journal of Economics and Finance, 47(December 2017), 391-405. https://doi.org/10.1016/j.najef.2018.05.006

Hausman, J. A., \& Taylor, W. E. (1981). Panel data and unobservable individual effects. Econometrica, 49(6), 1377-1398. https://www.jstor.org/stable/1911406

Hong, H., \& Kacperczyk, M. (2009). The price of sin: The effects of social norms on markets. Journal of Financial Economics, 93(1), 15-36. https://doi.org/10.1016/j. jfineco.2008.09.001

Huang, D., Jiang, F., Tu, J., \& Zhou, G. (2015). Investor sentiment aligned: A powerful predictor of stock returns. Review of Financial Studies, 28(3), 791-837. https://doi.org/10.1093/rfs/hhu080

Hussein, K., \& Omran, M. (2005). Ethical investment revisited: Evidence from Dow Jones Islamic Indexes. The Journal of Investing, 14(3), 105-126. https://doi. org/10.3905/joi.2005.580557

Ibrahim, M. (2020). Islamic banking and bank performance in Malaysia: An empirical analysis. Journal of Islamic Monetary Economics and Finance, 6(3), 487502. https://doi.org/10.21098/JIMF.V6I3.1197

Ibrahim, M. H. (2015). Issues in Islamic banking and finance: Islamic banks, Shari'ah-compliant investment and sukuk. Pacific Basin Finance Journal, 34, 185-191. https://doi.org/10.1016/j.pacfin.2015.06.002

IFSB. (2020). Islamic financial service industry stability report 2020.

Jaballah, J., Peillex, J., \& Weill, L. (2018). Is being Sharia compliant worth it? Economic Modelling, 72, 353-362. https://doi.org/10.1016/j.econmod.2018.02.011

Jaziri, M., \& Abdelhedi, M. (2018). Islamic occasions and investor sentiment. International Journal of Islamic and Middle Eastern Finance and Management, 11(2), 194-212. https://doi.org/10.1108/IMEFM-08-2017-0225

Jensen, M. C. (1968). Problems in selection of security portfolios the performance of mutual funds in the period 1945-1964. Journal of Finance, 23(2), 389-416.

Keleş, E., \& Çetin, A. (2018). Corporate social responsibility, investor sentiment, and stock returns. In Sustainability and Social Responsibility: Regulation and Reporting (pp. 141-157). https://doi.org/10.1007/978-981-10-4502-8

Khan, M. A., Hernandez, J. A., \& Shahzad, S. J. H. (2019). Time and frequency relationship between household investors' sentiment index and US industry stock returns. Finance Research Letters, May, 101318. https://doi.org/10.1016/j. frl.2019.101318

Kim, K. A., \& Nofsinger, J. R. (2008). Behavioral finance in Asia. Pacific Basin Finance Journal, 16(1-2), 1-7. https://doi.org/10.1016/j.pacfin.2007.04.001

Koesrindartoto, D. P., Aaron, A., Yusgiantoro, I., Dharma, W. A., \& Arroisi, A. (2020). Who moves the stock market in an emerging country - Institutional or 
retail investors? Research in International Business and Finance, 51(June 2019), 101061. https://doi.org/10.1016/j.ribaf.2019.101061

Kumari, J. (2019). Investor sentiment and stock market liquidity: Evidence from an emerging economy. Journal of Behavioral and Experimental Finance, 23, 166-180. https://doi.org/10.1016/j.jbef.2019.07.002

Lan, Y., Huang, Y., \& Yan, C. (2020). Investor sentiment and stock price: Empirical evidence from Chinese SEOs. Economic Modelling, January. https:/doi. org/10.1016/j.econmod.2020.02.012

Liao, T. L., Huang, C. J., \& Wu, C. Y. (2011). Do fund managers herd to counter investor sentiment? Journal of Business Research, 64(2), 207-212. https://doi. org/10.1016/j.jbusres.2010.01.007

Lintner, J. (1965). The Valuation of risk assets and the selection of risky investments in stock portfolios and capital budgets. The Review of Economics and Statistics, 51(2), 222-224 https://doi.org/10.2307/1924119

Liston-Perez, D., Torres-Palacio, P., \& Bayram, S. G. (2018). Does investor sentiment predict Mexican equity returns? International Journal of Managerial Finance, 14(4), 484-502. https://doi.org/10.1108/IJMF-05-2017-0088

Lusyana, D., \& Sherif, M. (2017). Shariah-compliant investments and stock returns: Evidence from the Indonesian stock market. Journal of Islamic Accounting and Business Research, 8(2), 143-160. https://doi.org/10.1108/JIABR-10-2015-0052

Maddala, G. S., \& Wu, S. (1999). A comparative study of unit root tests with panel data and a new simple test. Oxford Bulletin of Economics and Statistics, 61(s1), 631-652. https://doi.org/10.1111/1468-0084.61.s1.13

Majdoub, J., Mansour, W., \& Jouini, J. (2016). Market integration between conventional and Islamic stock prices. North American Journal of Economics and Finance, 37, 436-457. https://doi.org/10.1016/j.najef.2016.03.004

Masih, M., Kamil, N. K. M., \& Bacha, O. I. (2018). Issues in Islamic equities: A literature survey. Emerging Markets Finance and Trade, 54(1), 1-26. https://doi.or g/10.1080/1540496X.2016.1234370

Mateus, I. B., Mateus, C., \& Todorovic, N. (2019). Review of new trends in the literature on factor models and mutual fund performance. International Review of Financial Analysis, 63(October 2018), 344-354. https://doi.org/10.1016/j. irfa.2018.12.012

McPherson, M. Q., \& Trumbull, W. N. (2008). Rescuing observed fixed effects: Using the Hausman-Taylor method for out-of-sample trade projections. International Trade Journal, 22(3), 315-340. https://doi.org/10.1080/08853900802191389

Mendel, B., \& Shleifer, A. (2012). Chasing noise. Journal of Financial Economics, 104(2), 303-320. https://doi.org/10.1016/j.jfineco.2011.02.018

Miwa, K. (2016). Investor sentiment, stock mispricing, and long-term growth expectations. Research in International Business and Finance, 36, 414-423. https:// doi.org/10.1016/j.ribaf.2015.10.003

OJK. (2017). Peraturan Otoritas Jasa Keuangan No. 35 /POJK.04/2017 Tentang Kriteria dan Penerbitan Daftar Efek Syariah. [About Criteria and Issuance of List of Sharia Securities] https://www.ojk.go.id/id/kanal/pasar-modal/regulasi/ peraturan-ojk/Documents/Pages/Peraturan-Otoritas-Jasa-Keuangan-Nomor35-POJK.04-2017-/SAL POJK 35 - DES.pdf

OJK. (2018). Laporan Perkembangan Keuangan Syariah Indonesia. In OJK. 
Pandey, P., \& Sehgal, S. (2019). Investor sentiment and its role in asset pricing: An empirical study for India. IIMB Management Review, 31(2), 127-144. https://doi. org/10.1016/j.iimb.2019.03.009

Perez-Liston, D., Huerta, D., \& Haq, S. (2016). Does investor sentiment impact the returns and volatility of Islamic equities? Journal of Economics and Finance, 40(3), 421-437. https://doi.org/10.1007/s12197-014-9290-6

Pesaran, M. H. (2015). Time series and panel data econometrics. Oxford University Press.

Qadan, M., \& Aharon, D. Y. (2019). Can investor sentiment predict the size premium? International Review of Financial Analysis, 63(January), 10-26. https:// doi.org/10.1016/j.irfa.2019.02.005

Qoyum, A., Al Hashfi, R. U., Zusryn, A. S., Kusuma, H., \& Qizam, I. (2020). Does an islamic-sri portfolio really matter? Empirical application of valuation models in indonesia. Borsa Istanbul Review, (Article in Press). https://doi.org/10.1016/j. bir.2020.08.002

Rahman, M. L., \& Shamsuddin, A. (2019). Investor sentiment and the priceearnings ratio in the G7 stock markets. Pacific Basin Finance Journal, 55(March), 46-62. https://doi.org/10.1016/j.pacfin.2019.03.003

Ramiah, V., Xu, X., \& Moosa, I. A. (2015). Neoclassical finance, behavioral finance and noise traders: A review and assessment of the literature. International Review of Financial Analysis, 41, 89-100. https://doi.org/10.1016/j.irfa.2015.05.021

Reddy, K., Mirza, N., Naqvi, B., \& Fu, M. (2017). Comparative risk adjusted performance of Islamic, socially responsible and conventional funds: Evidence from United Kingdom. Economic Modelling, 66(July 2016), 233-243. https://doi. org/10.1016/j.econmod.2017.07.007

Ross, S. A. (1976). The arbitrage theory of capital asset pricing. Journal of Economic Theory, 13(3), 341-360. https://doi.org/10.1016/0022-0531(76)90046-6

Ryu, D., Kim, H., \& Yang, H. (2017). Investor sentiment, trading behavior and stock returns. Applied Economics Letters, 24(12), 826-830. https://doi.org/10.108 0/13504851.2016.1231890

Seok, S. I., Cho, H., \& Ryu, D. (2019a). Firm-specific investor sentiment and daily stock returns. North American Journal of Economics and Finance, 50(April 2018), 100857. https://doi.org/10.1016/j.najef.2018.10.005

Seok, S. I., Cho, H., \& Ryu, D. (2019b). Firm-specific investor sentiment and the stock market response to earnings news. North American Journal of Economics and Finance, 48(January), 221-240. https://doi.org/10.1016/j.najef.2019.01.014

Shaikh, S. A., Ismail, M. A., Ismail, A. G., Shahimi, S., \& Mohd. Shafiai, M. H. (2019). Cross section of stock returns on Shari'ah -compliant stocks: evidence from Pakistan. International Journal of Islamic and Middle Eastern Finance and Management, 12(2), 282-302. https://doi.org/10.1108/IMEFM-04-2017-0100

Sharpe, W. F. (1964). Capital asset prices: A theory of market equilibrium under conditions of risk. The Journal of Finance, 19(3), 425-442. https://doi. org/10.1111/j.1540-6261.1964.tb02865.x

Shleifer, A., \& Summers, L. H. (1990). The noise trader approach to finance. Journal of Economic Perspectives, 4(2), 19-33. https://doi.org/10.1257/jep.4.2.19

Spyrou, S. (2012). Sentiment changes, stock returns and volatility: Evidence from NYSE, AMEX and NASDAQ stocks. Applied Financial Economics, 22(19), 16311646. https://doi.org/10.1080/09603107.2012.671921 
Stambaugh, R. F., \& Yuan, Y. (2017). Mispricing factors. The Review of Financial Studies, 30(4), 1270-1315. https://doi.org/10.1093/rfs/hhw107

Statman, M. (2014). Behavioral finance: Finance with normal people. Borsa Istanbul Review, 14(2), 65-73. https://doi.org/10.1016/j.bir.2014.03.001

Walkshäusl, C., \& Lobe, S. (2012). Islamic investing. Review of Financial Economics, 21(2), 53-62. https://doi.org/10.1016/j.rfe.2012.03.002

Wooldridge, J. M. (2018). Introductory Econometrics (7th Edition). Cengage Learning, Inc.

Yang, C., \& Zhou, L. (2015). Investor trading behavior, investor sentiment and asset prices. North American Journal of Economics and Finance, 34, 42-62. https:// doi.org/10.1016/j.najef.2015.08.003

Yao, C. Z., \& Li, H. Y. (2020). Time-varying lead-lag structure between investor sentiment and stock market. North American Journal of Economics and Finance, 52(November 2019), 101148. https://doi.org/10.1016/j.najef.2020.101148

Zaremba, A., Karathanasopoulos, A., Maydybura, A., Czapkiewicz, A., \& Bagheri, N. (2018). Dissecting anomalies in Islamic stocks: Integrated or segmented pricing? Pacific Basin Finance Journal, March. https://doi.org/10.1016/j. pacfin.2018.05.006

Zhang, D., Lei, L., Ji, Q., \& Kutan, A. M. (2019). Economic policy uncertainty in the US and China and their impact on the global markets. Economic Modelling, 79(March), 47-56. https://doi.org/10.1016/j.econmod.2018.09.028

Zhang, R., Xian, X., \& Fang, H. (2019). The early-warning system of stock market crises with investor sentiment: Evidence from China. International Journal of Finance $\mathcal{E}$ Economics, 24(1), 361-369. https://doi.org/10.1002/ijfe.1667

Zhu, Z., Sun, L., \& Yung, K. (2020). Fundamental strength strategy: The role of investor sentiment versus limits to arbitrage. International Review of Financial Analysis, 101452. https://doi.org/10.1016/j.irfa.2020.101452 